\title{
Habitat selection and reproductive success of coot Fulica atra on ponds under different fish size and density conditions
}

\author{
Marek Nieoczym (10) Janusz Kloskowski
}

Received: 16 January 2018/Revised: 9 May 2018/Accepted: 21 May 2018/Published online: 31 May 2018

(C) The Author(s) 2018

\begin{abstract}
Fish may influence habitat selection and reproductive success in waterfowl. We investigated the effects of common carp Cyprinus carpio on breeding coots Fulica atra along a gradient of fish size structure and density, created by separate stocking of age cohorts in ponds in eastern Poland. Coot breeding densities were higher on ponds with low biomass of small-sized, young-of-the-year fish than on ponds with medium- or large-sized fish, stocked at high biomass densities; they also increased with increasing submerged vegetation biomass (an effect correlated with water transparency) and emergent vegetation cover. Densities of nektonic and epibenthic macroinvertebrates and of amphibian larvae were also negatively influenced by fish size/density gradient, while densities of emerging insects were not affected. However, coot breeding success per pair was similar among pond types, while positively related to submerged vegetation, indicating that either plant food abundance was more important than the overall
\end{abstract}

Handling editor: Stuart Halse

M. Nieoczym $(\bowtie)$

Department of Zoology, Animal Ecology and Hunting,

University of Life Sciences, Akademicka 13,

20-033 Lublin, Poland

e-mail: mnieoczy@wp.pl

J. Kloskowski

Institute of Zoology, Poznań University of Life Sciences,

Wojska Polskiego 71C, 60-625 Poznan, Poland trophic impact of fish or fledgling production was additionally limited by factors other than food. Carp may adversely affect pond habitats of waterfowl both via trophic interactions and through abiotic disturbance of ecosystem processes. In coots, however, the effects can be mitigated by maintenance of abundant emergent vegetation and of submerged macrophytes resistant to fish.

Keywords Anthropogenic ponds · Common carp · Fish-bird interactions · Food supply · Herbivory · Waterfowl

\section{Introduction}

Interactions with fish can be crucial for habitat selection and breeding success in many waterbird species. These interactions include food competition and reciprocal predation, but also a wide array of indirect fish effects, ranging from ecological engineering to behavioural responses to fish by prey common to fish and aquatic birds (Hurlbert et al., 1986; Giles, 1994; Hanson \& Butler, 1994; Haas et al., 2007; LeBourdais et al., 2009). The role of fish in structuring waterbird communities has grown in importance with increasing intensification of fishrelated management of inland waters, including world-wide fish introductions and conversion of 
wetlands to aquaculture. Many waterfowl species have experienced population changes linked to increased fish presence (Musil, 2006; Bajer et al., 2009; Nummi et al., 2016), probably because their roles in food webs are similar to those of fish, but little is known about the relationships between fish and one of the most common western Palearctic waterfowl species, the Eurasian Coot (Fulica atra Linnaeus, 1758). Owing to the often dominant position of coot in waterbird communities, particularly in shallow, eutrophic wetlands (e.g. Nilsson, 1978; Paracuellos, 2006; Haas et al., 2007), its trophic impact via grazing pressure on submerged macrophytes may have ecosystem-scale consequences, i.e. it may affect macrophyte abundance and community structure and contribute to shifts between a macrophyte-dominated clear water state to a phytoplankton-dominated turbid state, analogously to fish effects (Perrow et al., 1997; Søndergaard et al., 1997; van Altena et al., 2016; but see Hansson et al., 2010; Chaichana et al., 2011; Marco-Méndez et al., 2015). Coot populations have been shown to be sensitive to fish, presumably due to negative fish impact on submerged macrophytes and aquatic insects (Houdková \& Musil, 2003; MacedaVeiga et al., 2017), i.e. food resources of coots.

Farming of carp species in open ponds, the principal component of freshwater aquaculture industry in Central and Eastern Europe and Asia (Szücs et al., 2007), provides habitats for waterbirds, especially in areas where natural wetlands are sparse or have been converted to aquaculture (IUCN, 1997). Waterbirds that are not piscivorous are typically not deterred from fish ponds and may find suitable breeding conditions there. Coot densities have been reported to be considerably higher on carp ponds than on natural wetlands (Kozulin et al., 1998). On the other hand, cultured and widely stocked carp species are capable of adversely affecting entire ecosystems, both via trophic influences and habitat modification (Pípalová, 2006; Bajer et al., 2016; Collins \& Wahl, 2017). Common carp (Cyprinus carpio Linnaeus, 1758) is the most notorious for substantial top-down and bottomup effects through omnivorous feeding, mainly on detritus, benthic macroinvertebrates and zooplankton; however, the foraging-related abiotic influence of carp may create an even stronger disturbance pathway, with declines in water transparency and submerged macrophytes (Vilizzi et al., 2015; Kaemingk et al., 2017). Variation in ecosystem responses can be attributed to carp population characteristics (reviewed in Rahman, 2015; Vilizzi et al., 2015). Consequently, ponds used for carp rearing differ in their suitability for breeding birds, depending on culture conditions and intensity (IUCN, 1997; Musil, 2006; Broyer \& Calenge, 2010; see also Lemmens et al., 2015). Differential pond stocking practices provide an excellent opportunity to study the effects of fish on waterbirds, serving as a basis for large-scale whole-system natural experiments, where fish populations (and their impact on aquatic communities) are manipulated. Previous research on carp ponds has shown strong effects of fish individual size and density on habitat selection by waterbirds (Haas et al., 2007; Kloskowski et al., 2010). Typically, ponds with low fish biomass support the highest diversity and abundance of macroinvertebrates and submerged vegetation (Broyer \& Calenge, 2010; Nieoczym \& Kloskowski, 2015) and offer the most favourable conditions for many waterfowl, due to low competition for food during the chick stage (Hill et al., 1987; Hanson \& Butler, 1994; Haas et al., 2007). Other pond attributes, such as water area, nesting site availability and shelter from predators, can be important for bird habitat selection as well (e.g. Staicer et al., 1994; Paracuellos, 2006; Broyer \& Calenge, 2010). However, in human-managed aquatic systems, bird habitat preferences may not match the actual habitat suitability due to unpredictable habitat dynamics, such as seasonal changes in food supplies or water-level fluctuations (Anteau et al., 2012; Kloskowski, 2012). Here we used separate stocking of ponds with carp age cohorts as the context for a natural experiment to investigate coot habitat selection and breeding success in relation to the age structure of fish. Carp effects on aquatic ecosystems are size-dependent, as prey capture and ingestion are limited by gape size and because larger individuals tend to penetrate deeper into the sediments and to mobilise phosphorus through sediment suspension (Lammens \& Hoogenboezem, 1991; Driver et al., 2005; Kloskowski, 2011). The species has been reported to increase phytoplankton production and decrease water transparency and macrophyte coverage, with effects generally increasing with fish density (Weber \& Brown, 2015). Since under pond conditions fish age corresponds to combined fish individual size and density, the carp age gradient was equivalent to a gradient of carp trophic pressure on pond communities. We considered habitat variables related to the availability of animal and plant food, 
shelter, and nesting sites, all of which could be potentially affected by fish. We expected ponds with lower trophic pressure of fish to support higher levels of animal and plant food for waterfowl (Lemmens et al., 2013), leading to positive habitat selection and higher breeding success in coots.

\section{Materials and methods}

\section{Coot biology}

The coot is a semi-precocial species; chicks are brooded on the nest for about 3-4 days and then the nest is abandoned, although it often remains used by the family for roosting. The young start diving for food at 3-5 weeks old and gradually become independent of their parents by 6-8 weeks of age. Coots rarely raise two broods per season, but early clutch failure is typically followed by a replacement clutch, which occasionally may be repeated (Taylor, 1998). Coots rely on the feeding conditions provided by the nesting pond because breeding pairs are strictly territorial and family groups stay together in the same area of the pond at least until the chicks are self-supporting (Horsfall, 1984; Taylor, 1998; Varo, 2008).

Food is a substantial factor limiting reproductive success in coots (Horsfall, 1984; Brinkhof \& Cave, 1997). Coots rely on plant matter as the main food source during most of their life cycle (Hurter, 1972; Metna et al., 2015). During the breeding period, however, the share of animal food increases, because a protein-rich diet is crucial for breeding females and young birds (Borowiec, 1975; Horsfall, 1984; Brinkhof, 1997). Generally, the relative proportion of plant and animal matter in the diet of the species is highly dependent on available resources. The animal diet of coots consists of a variety of macroinvertebrates, including emerging aquatic insects, and to a lesser extent vertebrates, such as amphibian larvae and small fish (Collinge, 1936; Borowiec, 1975; Horsfall, 1984; Taylor, 1998).

Study system

The research was conducted on semi-natural managed, drainable ponds, scattered in loose clusters in an agricultural landscape north and west of the City of Lublin in south-eastern Poland $\left(51^{\circ} 17-33^{\prime} \mathrm{N}\right.$, $22^{\circ} 15-26^{\prime} \mathrm{E}$ ). The ponds were of similar depth (mean values varying from 0.7 to $1.3 \mathrm{~m}$ over the study period), ringed with emergent vegetation (mostly reeds Phragmites australis (Cav.) Trin. ex Steud, 1841 or bulrush Typha spp.), and with surface areas ranging from 1 to 13 ha (with one pond of $23 \mathrm{ha}$ ). They were filled with water from nearby rivers and precipitation from February until the end of March, and drained between September and November. A gradient of fish impact was created by stocking 3 year (size) cohorts of carp in separate ponds: young-of-theyear $(0+)$ fish, individual total length 3-4 mm (1.5-3.0 mg of weight), 1-year-old fish $(1+)$, 110-160 mm (about 30-60 g) or 2-year-old (2+) fish, 190-240 mm (about 140-300 g). The total biomass of $0+$ fish at stocking was practically negligible, but by mid-July it had reached about $50 \mathrm{~kg} / \mathrm{ha}$. The $1+$ fish were stocked at densities of 98-390 kg/ha and the $2+$ fish at 149-308 kg/ha, respectively. We assumed that fish impact on pond ecosystems should increase with age, i.e. with increasing individual size (and correlated biomass density) of stocked fish, although the $1+$ and $2+$ ponds differed in fish size but did not, on average, differ in total biomass. Young-of-the-year carp from July and older carp from May received broken cereal grains as supplemental feed, distributed in proportion to fish density, which could stimulate the productivity of the ponds and might be directly consumed by waterfowl; however, it was unlikely to contribute significantly to the coot diet during the breeding season, since the grains were supplied in a limited area of the pond, while breeding coots only feed within their own territories (Horsfall, 1984). Hunting of waterfowl, including coots, was permitted at all study ponds from 15 August, i.e. after the assumed end of the waterfowl breeding season, to 21 December. We collected data from 35 ponds altogether (12 ponds with $0+$ fish, 13 ponds with $1+$ fish and 10 ponds with $2+$ fish); 12 ponds were sampled per year in 2005 and 2007 and 11 ponds in 2006. A more detailed description of the study system is given in Nieoczym \& Kloskowski (2015).

\section{Coot surveys}

Coot counts were conducted during the breeding season from April to the first week of August at approximately weekly intervals. Coots were recorded using binoculars and spotting scopes by an observer 
walking along levees around the ponds (round count method, Koskimies \& Väisänen, 1991). The numbers of breeding pairs were estimated based on observations of territorial birds using the maximum number observed per pond in April-May. When estimating the number of pairs, single adults observed close to each other, i.e. presumably within the same territory, were added for total pair count; flocking birds were not considered breeders. Nests were not searched for systematically, but mainly along with other fieldwork activities in all pond types. Clutch size was determined in 89 nests for which the final egg number was confirmed during two visits at least 1 week apart. Pairs with broods were relatively easy to observe, as they usually fed on open water; for each pond the number of broods was estimated based on weekly surveys, eliminating from the records all repeated observations of the same brood, as indicated by mapped locations of broods and brood-tending adults and by the age of chicks. Broods hatched until the end of May were classified as 'early' and those hatched in June-July as 'late' (with a distinct break in the seasonal hatching pattern between 31 May and 8 June). Precise determination of hatching time was difficult in the absence of regular nest checks; in most pairs, complete hatching could be inferred only from observations of both parents with the brood off the nest. The hatching date of the clutch was backdated with accuracy of about 1 week based on the date of the earliest brood appearance and the colour characteristics of the chicks' plumage (Fjeldså, 1977).

We defined post-hatching breeding success as the maximum number of $>3$-week-old juveniles observed with parents; chicks close to fledging are difficult to assign to a brood due to the decreasing cohesiveness of family units. Coots 3 weeks and older differ in plumage characteristics from younger chicks in that they develop white cheeks and breast (Fjeldså, 1977). We assumed brood size at this age to be a reliable substitute for fledging success because coot chick mortality is concentrated within the first 2-3 weeks after hatching (Varo, 2008; Ręk, 2010). We used two measures of breeding success: per pair per season and per pair that successfully hatched at least one chick. We acknowledge the bias associated with each approach; as birds were not marked, when assessing breeding success per pair per season we could not ascertain whether any breeding pairs were occasionally replaced by other pairs in the territory; on the other hand, estimates of chick production based on successfully hatched nests may omit early brood losses and include repeated broods of pairs not classified as double-brooded.

\section{Habitat variables}

Data on fish stocks (fish age, size structure and stocking density) were obtained from local fisheries. Submerged and floating vegetation (including macroalgae such as Charophyta) was sampled once per breeding season during the maximum vegetation period, from 30 June and 2 July; eight samples were collected using a Bernatowicz rake along two perpendicular 30- to 45-m transects per pond. In the laboratory, dead plant litter was removed and live plants were identified to species, dried to constant weight and weighed to within $0.001 \mathrm{~g}$ (Nieoczym \& Kloskowski, 2014). Water transparency was measured using a 12-cm Secchi disc concurrently with the sampling of submerged vegetation. Nektonic and epibenthic macroinvertebrates and amphibian larvae were captured using submerged 1-1 activity traps, at half-month intervals between 20 April and 15 July (six sampling sessions per pond, 10 traps per session) at the interface between open water and emergent vegetation (for methodological details see Nieoczym \& Kloskowski, 2015). Macroinvertebrates, with the exception of leeches Hirudinea, were identified to at least order level, dried to constant weight and weighed. Of the invertebrate taxa captured by the traps, those known to be consumed by coots were included in the analyses: Gastropoda, Hirudinea, Odonata, Hemiptera, and Coleoptera (Taylor, 1998). Amphibian larvae were wet-weighed after drip-drying and released.

Emerging insects (Ephemeroptera and Diptera) were sampled using vertically positioned emergence traps between May and July in 2006 and 2007. In the second week of each month, ten 4-1 plastic traps (height $22 \mathrm{~cm}$ ) were deployed per pond for $24 \mathrm{~h}$. Each trap had an inverted funnel covering an area of $200 \mathrm{~cm}^{2}$ and a 41-mm opening at the narrow end (construction similar to that used by Danell \& Sjöberg, 1977). The greater part of the trap rested below the water surface. The traps were held in pairs by wooden stakes more or less evenly distributed in the open water area. The locations of the traps were the same during each trapping event. Trap contents were 
preserved in $70 \%$ ethanol; the number of emerging insects caught by a trap was based on the maximum number of either imagines or pupae, depending on which were more numerous. Catches from both activity traps and emergence traps can be influenced by water temperature, which determines oxygen solubility and affects invertebrate and larval amphibian activity, as well as the diel emergence patterns of insects (Henrikson \& Oscarson, 1978; Kureck, 1979; but see Murkin et al., 1983). To reduce the effects of temperature differences between ponds during trapping sessions, traps were set in all ponds on the same day (exceptionally with a 1-day difference). Sampling was conducted on sunny and windless days. Water temperature was taken using a thermometer suspended midway in the water column on the day of trap deployment (9.00 a.m.-4.00 p.m.).

We quantified pond area, shoreline length and proportional cover by emergent vegetation from digitised aerial photographs using the GIS-software QGIS 2.8 Wien. Data on the surrounding habitat matrix were available from aerial images; however, since our previous research on the local waterfowl communities indicated that landscape-level characteristics were insignificant for selection of the breeding pond (Kloskowski et al., 2010) and we were primarily interested in the effects of fish on breeding conditions, we focused on pond attributes.

\section{Data analysis}

Generalized linear mixed modelling (GLMM) with a $\log$ link and Poisson distribution was adopted to relate coot densities, clutch size and breeding success measures to habitat variables. Pair/brood densities were analysed at the pond level with year as a random term to take account of the non-independence of observations within years. An offset variable (the natural $\log$ of the pond surface area) was specified in the models to account for differences in pond size. Clutch size and breeding success were analysed at the pair level, with timing of breeding (early vs. late broods) as an additional fixed term and pond as a random factor. Year was omitted to simplify the models run at the level of individual pairs, as it was not significant when tested as a fixed effect. We did not account for pair density on the pond in the analyses, because it was not correlated with clutch or final brood size (all $P>0.8$ ). In the analyses of clutch size we limited habitat variables to fish gradient.

Prior to model construction, we used Pearson's coefficient to investigate relationships between predictor variables. Pond area was used in the analyses to calculate pair/brood densities. Since breeding territories on larger waterbodies may concentrate in the littoral zone near the shore, it could be argued that waterfowl numbers per unit of shoreline would be a better measure of waterfowl abundance than numbers per unit of water area (Nilsson, 1978). However, the ponds studied were uniformly shallow, often with scattered patches of emergent vegetation and coot nests in the central part of the pond, the whole flooded area corresponding to the littoral zone of stratified lakes. Moreover, the ponds were of regular shape and the shoreline length was strictly correlated with water area size $(r=0.92, P<0.001)$. Since fish gradient was assumed to be the causative factor controlling abundance of macroinvertebrates and amphibians (see "Results" section), to mitigate collinearity issues, nektonic macroinvertebrate and larval amphibian biomass were omitted from the mixed models. Similarly, submerged vegetation biomass was significantly correlated with Secchi depth $(r=0.36$, $P=0.034)$; submerged vegetation was retained for model selection since it yielded better univariate models and as a food source was assumed to be more important for breeding coots. Since the GLMMs included only 2-4 predictor terms, for predictions we considered full models. However, minimal models (the subsets of significant independent variables) achieved by backward stepwise selection yielded the same patterns of results.

Densities of newly hatched broods on ponds and the relative biomass abundances of macroinvertebrates known to be taken by coots and of amphibian larvae were compared between pond types using repeated measures (RMs-)ANOVA with count/sampling session as the repeated factor. Year identity was included as a fixed term in the RM-ANOVAs, but as it was not significant in any model (all $P>0.5$ ), it was omitted. A Greenhouse-Geisser correction was used when sphericity could not be assumed.

When necessary, data were natural log transformed to reduce heteroscedasticity. Two-tailed statistical significance was defined at the 0.05 level; means are given \pm 1 SE. Post hoc comparisons were performed using the least significant difference (LSD) test. The 
analyses were conducted in Statistica v. 13 (StatSoft, Inc.) and GenStat v. 15 (VSN International Ltd.).

\section{Results}

Over the 3 years, the total number of coot breeding pairs per year on the study ponds was estimated to be 201 (range of densities per pond $0-4.00 \mathrm{ha}^{-1}$, mean $1.41 \pm 0.17$ ). The earliest newly hatched broods were observed towards the end of April each year, and the latest in mid-July. Altogether we recorded 171 broods (78 early and 93 late broods) at densities varying between 0 and $3.6 \mathrm{ha}^{-1}$ (mean $1.10 \pm 0.16$ ).

GLMM models showed that both breeding pair and brood densities of coots were related to the fish gradient (Fig. 1) and increased with increasing biomass of submerged and floating vegetation in the pond (Table 1). Post hoc LSD tests indicated that $0+$ ponds supported higher numbers of pairs and broods than ponds with older-age fish. When Secchi transparency was entered into the model, replacing submerged vegetation, it proved significant as well (both $P<0.05)$. Clutch size did not differ between pond types $\left(F_{2,18}=1.44, P=0.264\right)$ or between early and late nesting attempts $\left(F_{1,}, 72=0.72, P=0.400\right)$. Similarly, models of breeding success showed no relationship with fish size structure/density (Fig. 2); however, breeding success per pair per season was

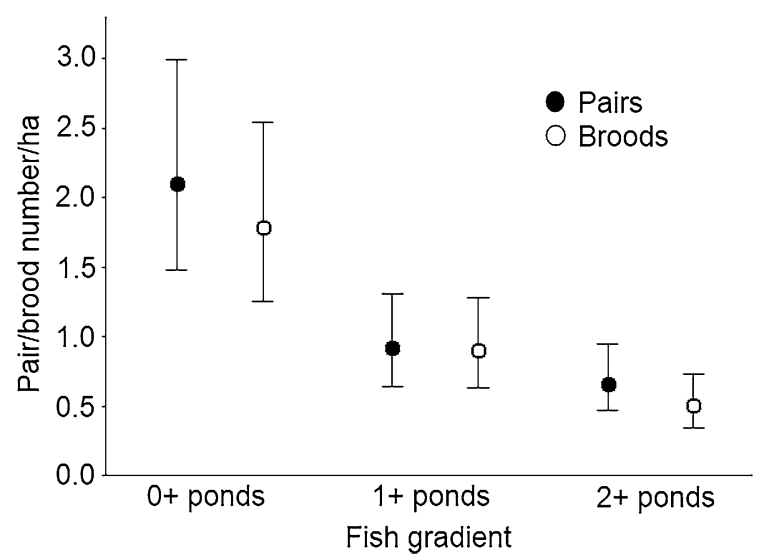

Fig. 1 Densities of breeding coot pairs and broods on ponds stocked separately with different-aged carp. The symbols and error bars represent back-calculated means and 95\% confidence limits (original scale), respectively, from GLMM models. $\log _{\mathrm{e}}$ pond surface area was modelled as an offset variable to control for differences in pond size positively related to submerged vegetation abundance, while the model of breeding success per successful nesting attempt indicated the importance of brood phenology, with early broods producing more fledglings than late broods (means $3.10 \pm 0.22$ vs. $2.47 \pm 0.20$, respectively; Table 1 ).

RM-ANOVA confirmed that densities of newly hatched broods throughout the breeding season depended on the fish gradient; the time effect was significant as well (Table 2). Fish gradient also had a significant influence on biomass abundance of macroinvertebrates and amphibians in ponds (Table 2; see also Fig. 3, where for the sake of illustration, data for all pond types were combined). In all RMANOVAs, both on brood and on nektonic and epibenthic prey densities, $0+$ ponds had significantly higher means than ponds with older-age fish (LSD tests). During the trapping sessions, water temperatures were similar between ponds and roughly consistent between years, showing a gradual increase until the end of June (Fig. 3A), with the exception of a cold spell in late May 2006, when the temperature in the ponds dropped to $13-15^{\circ} \mathrm{C}$. For the data pooled over pond types and the three study years, peak density of newly hatched broods coincided with peak abundances of macroinvertebrates and amphibians in early June. However, densities of newly hatched broods recorded throughout the season were not correlated with the concurrent levels of macroinvertebrates and larval amphibians (Spearman $r=0.26, P=0.623$ and $r=0.60, \quad P=0.208, \quad$ respectively, both $N=6$; Fig. 3B-D). Densities of emerging insects significantly declined with time in all pond types (RMANOVA $\left.F_{1,40}=3.86, P=0.029\right)$ and were not affected by the fish gradient $\left(F_{2,20}=1.41\right.$, $P=0.268$; Fig. 4). The emergence trap results may have been biased by the disproportionate occurrence of potential predators (leeches, Anisoptera nymphs, adult Dytiscidae and smooth newts Lissotriton vulgaris Linnaeus, 1758) that may consume insects as they emerge; in $0+$ ponds, mean fractions of traps with predators varied monthly between 20 and $41 \%$, while in ponds with older/larger fish on average only 1-2\% of the traps were invaded. Emerging insects were not recorded in emergence traps containing predators except for two traps invaded by dytiscids. 
Table 1 Results of GLMM analyses (Poisson errors, log link function) of the effects of habitat variables on (a) pair numbers and (b) brood numbers of coots on fish ponds, with year as a random factor and $\log _{\mathrm{e}}$ pond surface area as an offset variable, and on (c) breeding success per pair per season and (d) per pair with at least one chick hatched, with pond identity as a random factor

\begin{tabular}{|c|c|c|c|c|}
\hline Predictors & Estimate \pm SE & $F$-ratio & df & $P$ \\
\hline \multicolumn{5}{|l|}{ (a) Breeding pair number } \\
\hline Fish age $(0+, 1+, 2+)$ & $0.00,-0.83,-1.15(0.25)$ & 11.28 & 2,30 & $<0.001$ \\
\hline Submerged vegetation & $0.19 \pm 0.07$ & 7.12 & 1,30 & 0.012 \\
\hline Emergent pond vegetation & $1.41 \pm 0.67$ & 4.43 & 1,30 & 0.044 \\
\hline \multicolumn{5}{|l|}{ (b) Brood number } \\
\hline Fish age $(0+, 1+, 2+)$ & $0.00,-0.67,-0.98(0.08)$ & 6.02 & 2,30 & 0.006 \\
\hline Submerged vegetation & $0.24 \pm 0.08$ & 8.21 & 1,30 & 0.008 \\
\hline Emergent pond vegetation & $1.87 \pm 0.75$ & 6.30 & 1,30 & 0.018 \\
\hline \multicolumn{5}{|c|}{ (c) Breeding success (number of juveniles/pair) } \\
\hline Fish age $(0+, 1+, 2+)$ & $0.00,0.15,-0.04(0.17)$ & 0.69 & $2,15.4$ & 0.517 \\
\hline Submerged vegetation & $0.00 \pm 0.01$ & 5.23 & $1,19.2$ & 0.034 \\
\hline Emergent pond vegetation & $0.47 \pm 0.48$ & 0.94 & $1,28.1$ & 0.341 \\
\hline \multicolumn{5}{|c|}{ (d) Breeding success (number of juveniles/brood) } \\
\hline Fish age $(0+, 1+, 2+)$ & $0.00,-0.03,-0.19(0.17)$ & 0.64 & $2,17.1$ & 0.542 \\
\hline Submerged vegetation & $0.00 \pm 0.01$ & 0.14 & $1,14.1$ & 0.711 \\
\hline Emergent pond vegetation & $-0.14 \pm 0.42$ & 0.11 & $1,17.1$ & 0.749 \\
\hline Early/late broods & $0.00,-0.23(0.11)$ & 4.23 & $1,154.6$ & 0.041 \\
\hline
\end{tabular}

Timing of breeding (early vs. late broods) was added as a fixed term in the breeding success per brood analysis. For the categorical factors in the models (fish gradient, early vs. late broods), average standard errors of differences are shown in brackets

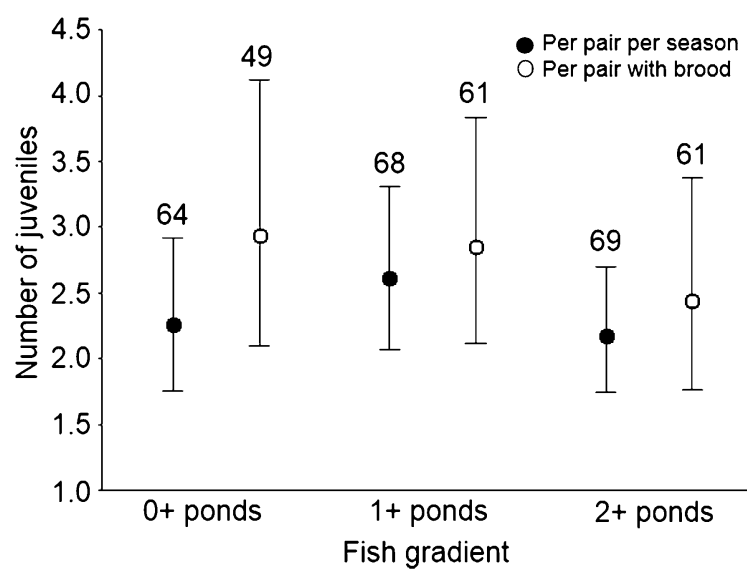

Fig. 2 Coot breeding success per pair per season and per brood (only pairs that successfully hatched at least one chick were included) on ponds stocked separately with different-aged carp. The symbols and error bars represent back-calculated means and 95\% confidence limits (original scale), respectively, from GLMM models. Sample sizes (numbers of broods) are shown above bars
Table 2 Repeated-measure ANOVA (with time as the repeated measure) for effects of fish gradient on the density of newly hatched coot broods and on the relative biomasses of macroinvertebrates and amphibian larvae

\begin{tabular}{llll}
\hline Source of variation & $\mathrm{df}$ & $F$ & $P$ \\
\hline Density of newly hatched broods/10 ha & & \\
Fish gradient & 2,32 & 5.55 & 0.009 \\
Time & 5,160 & 2.62 & 0.026 \\
Time $\times$ fish gradient & 10,160 & 0.64 & 0.777 \\
Dry biomass of invertebrates $(\mathrm{g})$ & & \\
Fish gradient & 2,32 & 11.43 & $<0.001$ \\
Time & 5,160 & 1.56 & 0.174 \\
Time $\times$ fish gradient & 10,160 & 1.26 & 0.257 \\
Wet biomass of tadpoles $(\mathrm{g})$ & & \\
Fish gradient & 2,32 & 4.31 & 0.022 \\
Time & 5,160 & 1.86 & 0.105 \\
Time $\times$ fish gradient & 10,160 & 1.88 & 0.051 \\
\hline
\end{tabular}


Fig. 3 Mean $( \pm$ SE) water temperatures (A), densities of newly hatched broods of $\operatorname{coot}(\mathbf{B})$, relative abundances (dry biomass per 10 traps) of nektonic and epibenthic

macroinvertebrates $(\mathbf{C})$, and relative abundances (wet biomass per 10 traps) of amphibian larvae

(D) throughout the breeding season ( $N=35$ ponds). $X$ axis numbers represent consecutive trapping events (at half-month intervals) and the concurrent coot counts. For clarity, data were pooled over pond types $(0+, 1+$ and $2+$ fish) and years (2005-2007)
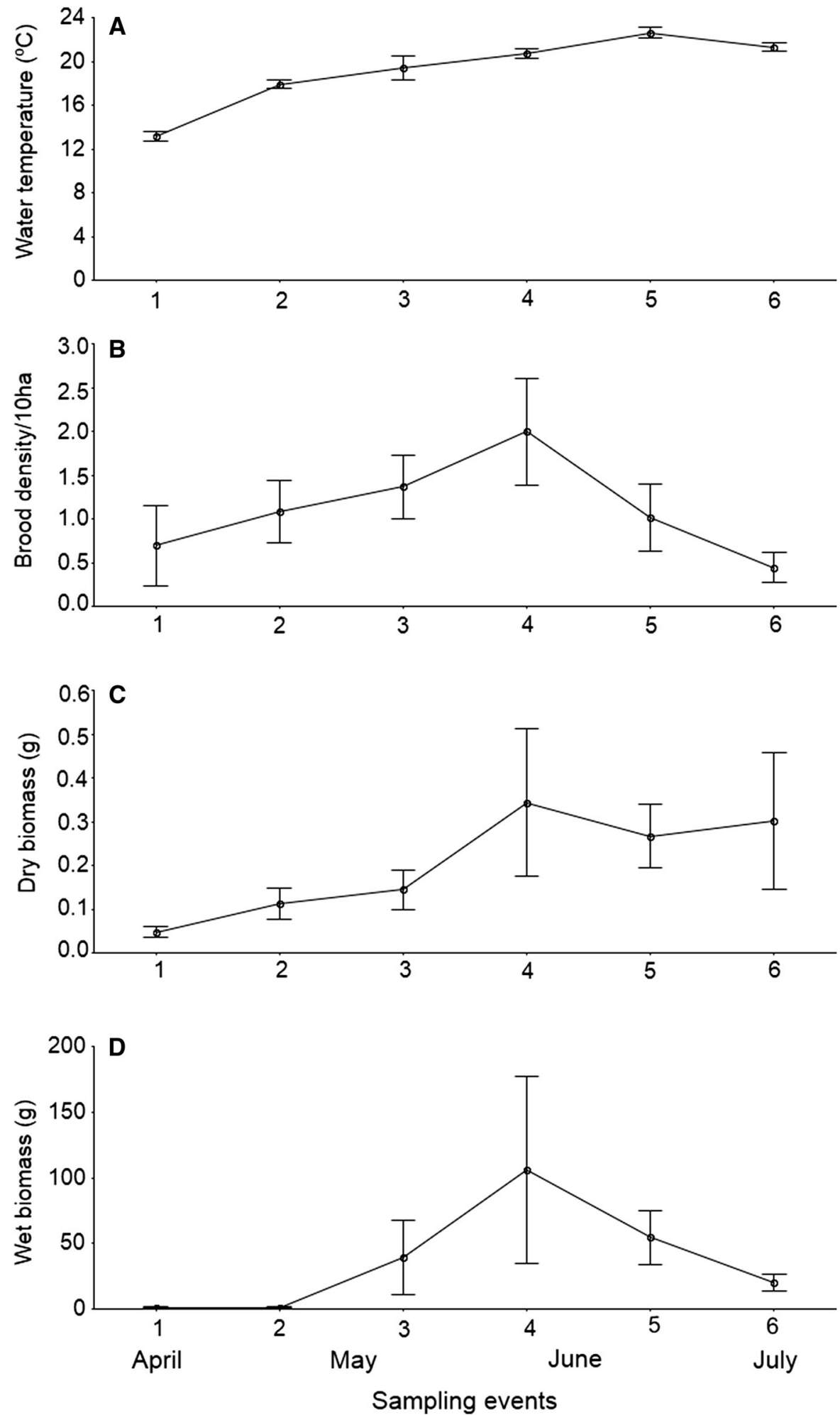


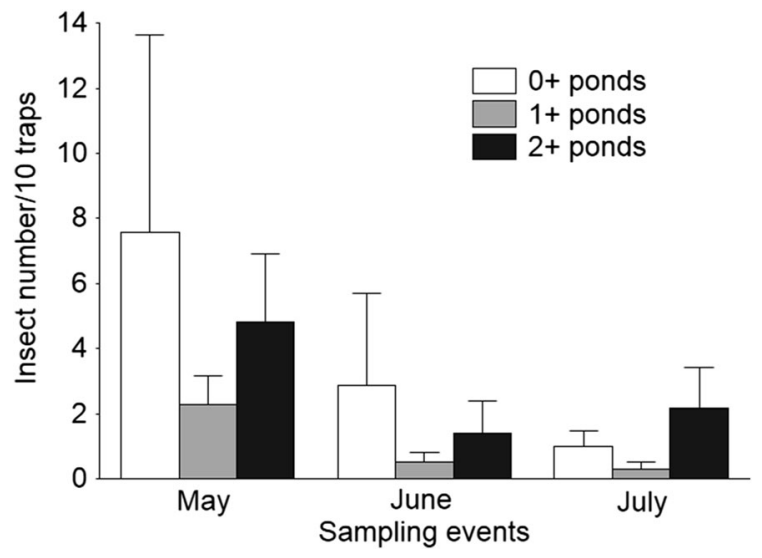

Fig. 4 Mean ( \pm SE) numbers of emerging insects (Ephemeroptera and Diptera) under different fish size and density conditions (ponds stocked with $0+, 1+$ and $2+$ carp; $N=7,10$ and 6 ponds, respectively) in May-July 2006-2007. Means and ranges of water temperatures at the time of trapping were $18^{\circ} \mathrm{C}$ $\left(15-21^{\circ} \mathrm{C}\right)$ in May, $21^{\circ} \mathrm{C}\left(16-23^{\circ} \mathrm{C}\right)$ in June and $21^{\circ} \mathrm{C}\left(18-23^{\circ} \mathrm{C}\right)$ in July

\section{Discussion}

Coot habitat selection in relation to fish impact on pond communities

Our data show that pond selection by breeding coots was driven by fish population characteristics (size structure combined with density) and abundance of emergent and submerged vegetation. Densities of breeding coots were considerably higher on low-fish $0+$ ponds than on ponds containing high biomass densities of larger carp. This pattern was consistent with fish effects on nektonic and epibenthic macroinvertebrate and larval amphibian availability, indicating food competition (or competition-related interactions) between carp and coots. The coincidence of brood hatching peak with the seasonally highest abundance of nektonic prey suggests that coots finetune egg-laying to the phenology of these prey resources. The competitive impact of carp on birds can be increased to a large degree by non-trophic (trait-mediated) interactions, since vagile adult insects and breeding amphibians avoid ponds with fish that pose a predation threat to their eggs and larvae (e.g. Resetaris \& Wilbur, 1989; Trekels \& Vanschoenwinkel, 2017), and these effects may be contingent on fish size and density (Kloskowski, 2011). Overall, we did not find differences in coot breeding parameters or food availability between $1+$ and $2+$ ponds, suggesting that at similar density levels of relatively largesized fish, the size structure of fish populations is of secondary importance.

Carp may also exert substantial pressure on submerged vegetation via resuspension of sediments, herbivory and uprooting (e.g. Sidorkewicj et al., 1996; Kaemingk et al., 2017; Maceda-Veiga et al., 2017), and thus diminish food resources for coots and destroy refugia and oviposition sites for invertebrates and amphibians (Diehl \& Kornijów, 1998). In our pond system, vegetation biomass was not significantly related to the fish gradient, presumably because turbidity levels during the avian breeding season only exceptionally exceeded 20 NTU (Nieoczym \& Kloskowski, 2014), a critical value over which plant development can be seriously hampered (Lougheed et al., 1998; see also Fischer et al., 2013). Carp impact on submerged vegetation and in turn on birds is likely to be more dramatic in warmer parts of the species' introduced range, where carp remain active over most of the year due to higher annual water temperatures (Maceda-Veiga et al., 2017). Some pond macrophytes, apparently more tolerant of turbid conditions and bottom stirring by benthivorous fish, persisted in the presence of densely stocked larger carp. In some $1+$ and $2+$ ponds, the only submerged macrophyte was sago pondweed (Stuckenia pectinata (L.) Börner, 1912) (Nieoczym \& Kloskowski, 2015), an important foraging resource for coots (Allouche \& Tamisier, 1984; Van Wijk, 1988; Hilt, 2006). Notably, carp have been reported to impair the growth of sago pondweed under experimental conditions through herbivory, increased water turbidity and stimulation of periphytic cover shading the macrophytes (Sidorkewicj et al., 1996, 1999; but see Lougheed et al., 1998; Miller \& Provenza, 2007). In our study system, coot breeding densities were related to both water transparency and abundance of submerged vegetation; these two habitat variables are considerably interdependent (e.g. Crowder \& Painter, 1991; Blindow et al., 1993; see also Kaemingk et al., 2017). Both submerged macrophytes as food resources and water transparency as a factor constraining prey detectability by diving birds (and also growth of macrophytes and charophytes) could be important for breeding waterfowl (Hanson \& Butler, 1994; Hargeby et al., 1994; Svingen \& Anderson, 1998; Musil, 2006; Hansson et al., 2010). 
Emergent vegetation was another pond variable important for habitat selection by coots, presumably because it provided nesting habitats and protection against aerial predators (Salathé, 1986). Luxuriance of emergent vegetation may also reduce competition with fish because coots feed on the shoots and leaves of emergent macrophytes (Borowiec, 1975; Allouche \& Tamisier, 1984; Metna et al., 2015). Adverse fish effects on waterfowl may be to some extent mitigated by high pond/lake productivity (e.g. Staicer et al., 1994; Broyer \& Calenge, 2010). Carp ponds are typically eutrophic and they receive additional nutrients from supplemental feeds, which are provided roughly in proportion to stock biomass. However, in the ponds studied fish gradient and surrogates for pond productivity were poorly correlated (Nieoczym \& Kloskowski, 2014; see also Nilsson, 1978 for the absence of a relationship between lake productivity and coot abundance).

\section{Coot breeding success}

The breeding response of coots to fish differed from those previously reported for waterbirds competitively interacting with fish. Some duck species have been shown to select their habitats to avoid fish and, consistently, despite greater breeding densities, their reproductive success (expressed as brood size or duckling growth) is higher on fish-free water bodies (Eriksson, 1979; DesGranges \& Rodrigue, 1986; Giles, 1994). Another contrasting response to fish was observed in facultatively piscivorous red-necked grebes (Podiceps grisegena Boddaert, 1783) nesting on carp ponds; breeding birds showed no habitat preference between $0+$ and $1+$ ponds and suffered heavy food-dependent mortality of chicks on the densely stocked $1+$ ponds, where fish proved unavailable to young birds due to size constraints and suppressed the non-fish prey of grebes (Kloskowski, 2012). In the present study, $0+$ ponds, supporting low densities of fish, were favoured by coots as nesting and brood-rearing habitats over densely stocked ponds with larger carp (see also Houdková \& Musil, 2003; Maceda-Veiga et al., 2017), but breeding success both per breeding pair and per nesting attempt resulting in the successful hatch of at least one egg did not differ among pond types. An adverse within-population density-dependent mechanism is unlikely, because pair density was not correlated with clutch or final brood size.

Given their high foraging plasticity and ability to use a wide array of plant and animal food (Perrow et al., 1997; Paracuellos, 2006), coots breeding under conditions of high competition with fish may be expected to rely on food resources less affected by fish, such as submerged macrophytes, as indicated by their positive effect on breeding success per pair per season. Macrophyte species able to tolerate the impact of fish might be of special importance in providing the quantities of food needed to meet the demands of broods. Of the animal food, most nektonic and epibenthic prey were obviously depressed by carp (cf. Nieoczym \& Kloskowski, 2015), so the only functional prey group unrelated to the fish gradient was emerging insects. Brinkhof (1997) showed that interannual and within-season differences in chick survival can be explained by variation in the abundance of emerging insects during the early posthatching period (see also Horsfall, 1984), similarly to the pattern observed in dabbling ducks, with most ducklings hatching just after the peak of emerging chironomids (Danell \& Sjöberg, 1977; Gardarsson \& Einarsson, 2004; but see Dessborn et al., 2009). In our study, coot dependence on emerging insects appears substantiated by the higher fledging success of early broods, since abundance of emerging insects declined throughout the coot breeding season (cf. Brinkhof \& Cave, 1997). Our emergence-trap data should be treated with caution, because in $0+$ ponds the traps were frequently invaded by predaceous macroinvertebrates and newts, readily feeding on emerging insects (Armitage, 1995). Studies using nektonic invertebrate traps have not found any significant effects of predators in the traps on the catches (e.g. Elmberg et al., 1992; Verdonschot, 2010). However, the disproportionate accumulation of predators in the traps placed in low-fish ponds was likely to bias the emergence rate estimates. Activity and emergence trap results could be confounded by intraseasonal variation in water temperature. However, we assume that our results were not significantly biased, because although water temperatures in the ponds progressively increased over most of the study period, they did not vary much from mid-May to July. Factors other than food could contribute to the similarity in survival rates of chicks between ponds, e.g. larger broods can attract predators and may be more difficult for their 
parents to protect (Ręk, 2010). Also, early-season cold spells during the nestling period could lead to increased mortality independent of food (authors' personal observations).

\section{Conclusions}

Fish proved an important factor in habitat selection by breeding coots, which should be considered in strategies of wetland management for waterfowl. Ponds with high fish impact (high fish densities, large individual size) supported the highest densities of coot broods. Owing to the complex nature of carp impact on pond communities, it is difficult to disentangle its biotic and abiotic influences on coot breeding conditions: largersized and/or more densely stocked carp are capable of both stronger food competition and bioturbation affecting foraging conditions (Kloskowski et al., 2010; Rahman, 2015; Vilizzi et al., 2015). On the other hand, although breeding densities were lower on ponds with larger and denser fish, coots settled on these ponds in considerable numbers and attained reproductive success comparable to that found on low-fish $0+$ ponds. We argue that owing to the broad feeding niche of coots (Taylor, 1998), their reproductive success need not strictly correspond to the level of fish trophic pressure. Our results suggest that to buffer the competitive effect of fish on waterfowl, it is crucial to preserve abundant emergent vegetation and submerged macrophytes resistant to fish activity; the vegetation may provide birds with food resources, both directly and also indirectly by offering microhabitats for animal prey.

Acknowledgements $\mathrm{We}$ are grateful to the fish farm managers, Maria Filipiak, Renata Grochowska and Jan Orzepowski, for their willingness to help with this study. Appreciation is expressed to Marcin Polak for assistance in nest searching. We thank Andy Green, Jan Kaczmarek and an anonymous reviewer for valuable comments on the manuscript. JK was supported by the Polish Ministry of Science and Higher Education (MNiSW) Grant No. 2 P04 G 05030.

Open Access This article is distributed under the terms of the Creative Commons Attribution 4.0 International License (http:// creativecommons.org/licenses/by/4.0/), which permits unrestricted use, distribution, and reproduction in any medium, provided you give appropriate credit to the original author(s) and the source, provide a link to the Creative Commons license, and indicate if changes were made.

\section{References}

Allouche, L. \& A. Tamisier, 1984. Feeding convergence of gadwall, coot and other herbivorous waterfowl species wintering in the Camargue: a preliminary approach. Wildfowl 35: 135-142.

Anteau, M. J., T. L. Shaffer, M. H. Sherfy, M. A. Sovada, J. H. Stacker, J. H. Stucker \& M. T. Wiltermuth, 2012. Nest survival of piping plovers at a dynamic reservoir indicates an ecological trap for a threatened population. Oecologia 170: 1167-1179.

Armitage, P. D., 1995. Chironomidae as food. In Armitage, P. D., P. S. Cranston \& L. C. V. Pinder (eds), The Chironomidae. Biology and Ecology of Non-biting Midges. Chapman and Hall, London: 423-435.

Bajer, P. G., G. Sullivan \& P. W. Sorensen, 2009. Effects of a rapidly increasing population of common carp on vegetative cover and waterfowl in a recently restored Midwestern shallow lake. Hydrobiologia 632: 235-245.

Bajer, P. G., M. W. Beck, T. K. Cross, J. D. Koch, W. M. Bartodziej \& P. W. Sorensen, 2016. Biological invasion by a benthivorous fish reduced the cover and species richness of aquatic plants in most lakes of a large North American ecoregion. Global Change Biology 22: 3937-3947.

Blindow, I., G. Andersson, A. Hargeby \& S. Johansson, 1993. Long-term pattern of alternative stable states in two shallow eutrophic lakes. Freshwater Biology 30: 159-167.

Borowiec, E., 1975. Food of the coot (Fulica atra L.) in different phonological periods. Polskie Archiwum Hydrobiologii 22: $157-166$.

Brinkhof, M. W., 1997. Seasonal variation in food supply and breeding success in European Coots Fulica atra. Ardea 85: 51-66.

Brinkhof, M. W. G. \& A. J. Cave, 1997. Food supply and seasonal variation in breeding success: an experiment in the European Coot. Proceedings of the Royal Society of London B: Biological Sciences 264: 291-296.

Broyer, J. \& C. Calenge, 2010. Influence of fish-farming management on duck breeding in French fish pond systems. Hydrobiologia 637: 173-185.

Chaichana, R., R. Leah \& B. Moss, 2011. Seasonal impact of waterfowl on communities of macrophytes in a shallow lake. Aquatic Botany 95: 39-44.

Collinge, W. E., 1936. The food and feeding-habits of the Coot (Fulica atra Linn.). Ibis 78: 35-39.

Collins, S. F. \& D. H. Wahl, 2017. Invasive planktivores as mediators of organic matter exchanges within and across ecosystems. Oecologia 184: 521-530.

Crowder, A. \& D. S. Painter, 1991. Submerged macrophytes in Lake Ontario: current knowledge, importance, threats to stability and needed studies. Canadian Journal of Fisheries and Aquatic Sciences 48: 1539-1545.

Danell, K. \& K. Sjöberg, 1977. Seasonal emergence of chironomids in relation to egg laying and hatching of ducks in a restored lake (northern Sweden). Wildfowl 28: 129-135.

DesGranges, J. L. \& J. Rodrigue, 1986. Influence of acidity and competition with fish on the development of ducklings in Quebec. Water, Air and Soil Pollution 30: 743-750.

Dessborn, L., J. Elmberg, P. Nummi, H. Pöysä \& K. Sjöberg, 2009. Hatching in dabbling ducks and emergence in 
chironomids: a case of predator-prey synchrony? Hydrobiologia 636: 319-329.

Diehl, S. \& R. Kornijów, 1998. Influence of submerged macrophytes on trophic interactions among fish and macroinvertebrates. In Jeppesen, E., Ma. Søndergaard, Mo. Søndergaard \& K. Christoffersen (eds), The Structuring Role of Submerged Macrophytes in Lakes. Ecological Studies, Vol. 131. Springer, New York: 24-46.

Driver, P. D., G. P. Closs \& T. Koen, 2005. The effects of size and density of carp (Cyprinus carpio L.) on water quality in an experimental pond. Archiv für Hydrobiologie 163: 117-131.

Elmberg, J., P. Nummi, H. Pöysä \& K. Sjöberg, 1992. Do intruding predators and trap position affect the reliability of catches in activity traps? Hydrobiologia 239: 187-193.

Eriksson, M. O. G., 1979. Competition between freshwater fish and goldeneyes Bucephala clangula (L.) for common prey. Oecologia 41: 99-107.

Fischer, J. R., R. M. Krogman \& M. C. Quist, 2013. Influences of native and non-native benthivorous fishes on aquatic ecosystem degradation. Hydrobiologia 711: 187-199.

Fjeldså, J., 1977. Guide to the Young of European Precocial Birds. Skarv Nature Publications, Tisvildeleje.

Gardarsson, A. \& A. Einarsson, 2004. Resource limitation of diving ducks at Myvatn: food limits production. Aquatic Ecology 38: 285-295.

Giles, N., 1994. Tufted Duck (Aythya fuligula) habitat use and brood survival increases after fish removal from gravel pit lakes. Hydrobiologia 279(280): 367-392.

Haas, K., U. Köhler, S. Diehl, P. Köhler, S. Dietrich, S. Holler, A. Jensch, M. Niedermaier \& J. Vilsmeier, 2007. Influence of fish on habitat choice of water birds: a whole-system experiment. Ecology 88: 2915-2925.

Hanson, M. A. \& M. G. Butler, 1994. Responses to food web manipulation in a shallow waterfowl lake. Hydrobiologia 279(280): 457-466.

Hansson, L. A., A. Nicolle, C. Brönmark, A. Hargeby, ̊. Lindström \& G. Andersson, 2010. Waterfowl, macrophytes, and the clear water state of shallow lakes. Hydrobiologia 646: 101-109.

Hargeby, A., G. Andersson, I. Blindow \& S. Johansson, 1994. Trophic web structure in a shallow eutrophic lake during a dominance shift from phytoplankton to submerged macrophytes. Hydrobiologia 279(280): 83-90.

Henrikson, L. \& H. Oscarson, 1978. A quantitative sampler for air-breathing aquatic insects. Freshwater Biology 8: 73-77.

Hill, D., R. Wright \& M. Street, 1987. Survival of mallard ducklings Anas platyrhynchos and competition with fish for invertebrates on a flooded gravel quarry in England. Ibis 129: 159-167.

Hilt, S., 2006. Recovery of Potamogeton pectinatus L. stands in a shallow eutrophic lake under extreme grazing pressure. Hydrobiologia 570: 95-99.

Horsfall, J. A., 1984. Food-supply and egg mass variation in the European Coot. Ecology 65: 89-95.

Houdková, B. \& P. Musil, 2003. Trends in numbers of the Coot (Fulica atra) in the Czech Republic in 1988-2000. Ornis Hungarica 12: 283-288.

Hurlbert, S. H., W. Loayza \& T. Moreno, 1986. Fish-flamingo plankton interactions in the Peruvian Andes. Limnology and Oceanography 31: 457-468.
Hurter, H.-U., 1972. Nahrung und Ernährungsweise des Blasshuhns Fulica atra am Sempachersee. Der Ornithologische Beobachter 69: 125-149.

IUCN, 1997. Fishing for a Living - The Ecology and Economics of Fishponds in Central Europe. IUCN, Gland.

Kaemingk, M. A., J. C. Jolley, C. P. Paukert, D. W. Willis, K. Henderson, R. S. Holland \& M. L. Lindvall, 2017. Common carp disrupt ecosystem structure and function through middle-out effects. Marine and Freshwater Research 68: $718-731$.

Kloskowski, J., 2011. Consequences of the size structure of fish populations for their effects on a generalist avian predator. Oecologia 166: 517-530.

Kloskowski, J., 2012. Fish stocking creates an ecological trap for an avian predator via effects on prey availability. Oikos 121: 1567-1576.

Kloskowski, J., M. Nieoczym, M. Polak \& P. Pitucha, 2010. Habitat selection by breeding waterbirds at ponds with size-structured fish populations. Naturwissenschaften 97: 673-682.

Koskimies, P. \& R. A. Väisänen, 1991. Monitoring Bird Populations. A Manual of Methods Applied in Finland. Zoological Museum, Finnish Museum of Natural History, University of Helsinki, Helsinki.

Kozulin, A., V. Yourko, O. Pareiko, T. Pavlushchick \& N. Tcherkas, 1998. Waterfowl in Belarus - population estimates and habitat changes. Acta Ornithologica 33: 113-126.

Kureck, A., 1979. Two circadian eclosion times in Chironomus thummi (Diptera), alternately selected with different temperatures. Oecologia 40: 311-323.

Lammens, E. H. R. R. \& W. Hoogenboezem, 1991. Diets and feeding behaviour. In Winfield, I. J. \& J. S. Nelson (eds), Cyprinid Fishes: Systematics, Biology and Exploitation. Fish and Fisheries Series 3. Chapman and Hall, London: 353-376.

LeBourdais, S. V., R. C. Ydenberg \& D. Esler, 2009. Fish and harlequin ducks compete on breeding streams. Canadian Journal of Zoology 87: 31-40.

Lemmens, P., J. Mergeay, T. De Bie, J. Van Wichelen \& L. De Meester, 2013. How to maximally support local and regional biodiversity in applied conservation? Insights from pond management. PLoS ONE 8: e72538.

Lemmens, P., J. Mergeay, J. Van Wichelen, L. De Meester \& S. A. J. Declerck, 2015. The impact of conservation management on the community composition of multiple organism groups in eutrophic interconnected man-made ponds. PLoS ONE 10: e0139371.

Lougheed, V. L., B. Crosbie \& P. Chow-Fraser, 1998. Predictions on the effect of common carp (Cyprinus carpio) exclusion on water quality, zooplankton and submergent macrophytes in a Great Lakes Wetland. Canadian Journal of Fisheries and Aquatic Sciences 55: 1189-1197.

Maceda-Veiga, A., R. López \& A. J. Green, 2017. Dramatic impact of alien carp Cyprinus carpio on globally threatened diving ducks and other waterbirds in Mediterranean shallow lakes. Biological Conservation 212: 74-85.

Marco-Méndez, C., P. Prado, L. M. Ferrero-Vicente, C. Ibáñez \& J. L. Sánchez-Lizaso, 2015. Seasonal effects of waterfowl grazing on submerged macrophytes: the role of flowers. Aquatic Botany 120: 275-282. 
Metna, F., A. Lardjane-Hamiti, N. Boukhemza-Zemmouri, M. Boukhemza, S. Merabet \& R. Abba, 2015. Diet of the Coot Fulica atra (Aves, Rallidae) in the nature reserve of Lake Réghaïa (Algiers, Algeria). Zoology and Ecology 25: 34-45.

Miller, S. A. \& F. D. Provenza, 2007. Mechanisms of resistance of freshwater macrophytes to herbivory by invasive juvenile common carp. Freshwater Biology 52: 39-49.

Murkin, H. R., P. G. Abbott \& J. A. Kadlec, 1983. A comparison of activity traps and sweep nets for sampling nektonic invertebrates in wetlands. Freshwater Invertebrate Biology 2: $99-106$

Musil, P., 2006. A review of the effects of intensive fish production on waterbird breeding populations. In Boere, G. C., C. A. Galbraith \& D. A. Stroud (eds), Waterbirds Around the World. The Stationery Office, Edinburgh: 520-521.

Nieoczym, M. \& J. Kloskowski, 2014. The role of body size in the impact of common carp Cyprinus carpio on water quality, zooplankton, and macrobenthos in ponds. International Review of Hydrobiology 99: 212-221.

Nieoczym, M. \& J. Kloskowski, 2015. Responses of epibenthic and nektonic macroinvertebrate communities to a gradient of fish size in ponds. Journal of Limnology 74: 50-62.

Nilsson, L., 1978. Breeding waterfowl in eutrophicated lakes in south Sweden. Wildfowl 29: 101-110.

Nummi, P., V. M. Väänänen, S. Holopainen \& H. Pöysä, 2016. Duck-fish competition in boreal lakes - a review. Ornis Fennica 93: 67-76.

Paracuellos, M., 2006. How can habitat selection affect the use of a wetland complex by waterbirds? Biodiversity and Conservation 15: 4569-4582.

Perrow, M. R., J. H. Schutten, J. R. Howes, T. Holzer, F. J. Madgwick \& A. J. D. Jowitt, 1997. Interactions between coot (Fulica atra) and submerged macrophytes: the role of birds in the restoration process. Hydrobiologia 342(343): 241-255.

Pípalová, I., 2006. A review of grass carp use for aquatic weed control and its impact on water bodies. Journal of Aquatic Plant Management 44: 1-12.

Rahman, M. M., 2015. Role of common carp (Cyprinus carpio) in aquaculture production systems. Frontiers in Life Science 8: 399-410.

Ręk, P., 2010. Testing the relationship between clutch size and brood size in the Coot (Fulica atra). Journal of Ornithology 151: $163-168$.

Resetaris Jr., W. J. \& H. M. Wilbur, 1989. Choice of oviposition site by Hyla chrysoscelis: role of predators and competitors. Ecology 70: 220-228.

Salathé, T., 1986. Habitat use by Coots nesting in a Mediterranean wetland. Wildfowl 37: 163-171.

Sidorkewicj, N. S., A. L. Cazorla \& O. A. Fernandez, 1996. The interaction between Cyprinus carpio L. and Potamogeton pectinatus L. under aquarium conditions. Hydrobiologia 340: 271-275.

Sidorkewicj, N. S., A. L. Cazorla, O. A. Fernandez, G. C. Möckel \& M. A. Burgos, 1999. Effects of Cyprinus carpio on Potamogeton pectinatus in experimental culture: the incidence of the periphyton. Hydrobiologia 415: 13-19.

Søndergaard, M., T. L. Lauridsen, E. Jeppesen \& L. Bruun, 1997. Macrophyte-waterfowl interactions: tracking a variable resource and the impact of herbivory on plant growth. In Jeppesen, E., Ma. Søndergaard, Mo. Søndergaard \& K. Christoffersen (eds), The Structuring Role of Submerged Macrophytes in Lakes. Ecological Studies, Vol. 131. Springer, New York: 298-307.

Staicer, C. A., B. Freedman, D. Srivastava, N. Dowd, J. Kilgar, J. Hayden, F. Payne \& T. Pollock, 1994. Use of lakes by black duck broods in relation to biological, chemical, and physical features. Hydrobiologia 279: 185-199.

Svingen, D. \& S. H. Anderson, 1998. Waterfowl management on grass-sage stock ponds. Wetlands 18: 84-89.

Szücs, I., L. Stundi \& L. Váradi, 2007. Carp farming in Central and Eastern Europe and a case study in multifunctional aquaculture. In Leung, P. S., C.-S. Lee \& P. J. O'Bryan (eds), Species and System Selection for Sustainable Aquaculture. Blackwell Publishing, Ames: 389-413.

Taylor, B., 1998. Rails: A Guide to the Rails, Crakes, Gallinules and Coots of the World. Pica Press, Sussex.

Trekels, H. \& B. Vanschoenwinkel, 2017. When fear kicks in: predator cues initially do not but eventually do affect insect distribution patterns in a new artificial pond cluster. Hydrobiologia 790: 157-166.

van Altena, C., E. S. Bakker, J. J. Kuiper \& W. M. Mooij, 2016. The impact of bird herbivory on macrophytes and the resilience of the clear-water state in shallow lakes: a model study. Hydrobiologia 777: 197-207.

Van Wijk, R. J., 1988. Ecological studies on Potamogeton pectinatus L. I. General characteristics, biomass production and life cycles under field conditions. Aquatic Botany 31: 211-258.

Varo, N., 2008. Breeding biology of two sympatric coots with contrasting conservation status. Bird Study 55: 314-320.

Verdonschot, R. C., 2010. Optimizing the use of activity traps for aquatic biodiversity studies. Journal of the North American Benthological Society 29: 1228-1240.

Vilizzi, L., A. S. Tarkan \& G. H. Copp, 2015. Experimental evidence from causal criteria analysis for the effects of common carp Cyprinus carpio on freshwater ecosystems: a global perspective. Reviews in Fisheries Science and Aquaculture 23: 253-290.

Weber, M. J. \& M. L. Brown, 2015. Biomass-dependent effects of age- 0 common carp on aquatic ecosystems. Hydrobiologia 742: 71-80. 